Review

\title{
Development of Sustainable Energy Use with Attention to Fruitful Policy
}

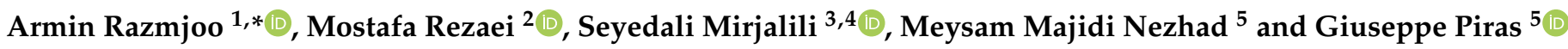 \\ 1 Escola Técnica Superior dÉnginyeria Industrial de Barcelona (ETSEIB), \\ Universitat Politécnica de Catalunya (UPC), Av. Diagonal, 647, 08028 Barcelona, Spain \\ 2 Queensland Micro- and Nanotechnology Centre, Griffith University, Nathan, QLD 4111, Australia; \\ mostafa.rezaei@griffithuni.edu.au \\ 3 Centre for Artificial Intelligence Research and Optimisation (AIRO), Torrens University Australia, \\ Adelaide, SA 5000, Australia; ali.mirjalili@gmail.com \\ 4 Yonsei Frontier Lab (YFL), Yonsei University, Seoul 03722, Korea \\ 5 Department of Astronautics, Electrical and Energetic Engineering (DIAEE), Sapienza University, \\ Via Edossiana 18, 00184 Rome, Italy; Meysam.majidinezhad@uniroma1.it (M.M.N.); \\ giuseppe.piras@uniroma1.it (G.P.) \\ * Correspondence: arminupc1983@gmail.com
}

Citation: Razmjoo, A.; Rezaei, M.; Mirjalili, S.; Majidi Nezhad, M.; Piras, G. Development of Sustainable Energy Use with Attention to Fruitful Policy. Sustainability 2021, 13, 13840. https://doi.org/10.3390/su132413840

Academic Editor: Elena Lucchi

Received: 5 November 2021

Accepted: 1 December 2021

Published: 15 December 2021

Publisher's Note: MDPI stays neutral with regard to jurisdictional claims in published maps and institutional affiliations.

Copyright: (c) 2021 by the authors. Licensee MDPI, Basel, Switzerland. This article is an open access article distributed under the terms and conditions of the Creative Commons Attribution (CC BY) license (https:// creativecommons.org/licenses/by/ $4.0 /)$.

\begin{abstract}
There are different energy approaches around the world to the development of sustainable energy systems. In this regard, the role of governments, local governments, and people in the development and use of sustainable energy is remarkable. This research, concerning the present epistemic and normative differences, aims to investigate the societal debate on citizen inclusion, local and national attempts to develop clear procedures and guidelines in the transition to sustainable energy use in different countries. Existing theories, subjectivities, and policy implications for different countries are first carefully analyzed. Based on theories, evidence, and policy implications, the behavioural insights for sustainable energy use are then examined. The results show that national governments should never ignore the psychology and behaviour of people, especially in terms of economic behaviour, performance applicable and knowledge of local governments and people in sustainable energy development. Channels of communication between local, people, and national governments, can make a robust shared network and implement simple policies such as increasing their authority. They can also encourage and build capacity through the training, support, trust and knowledge capacity of local governments and people to move toward sustainable energy development. Therefore, focusing on government and maintaining national authority should be departed from any approaches that local government and the public should be constrained as minor actors in sustainable energy governance networks. This work demonstrates that local governments can develop sustainable energy. Moreover, national governments can overcome issues and further control sustainable energy public policy goals under difficult national political conditions.
\end{abstract}

Keywords: sustainable energy use; behavioral insights; energy policy implications; governments

\section{Introduction}

Increasing energy consumption, global warming and population growth have emerged over the past decades as significant global challenges in the future [1]. In this regard, sustainable energy use has been considered one of the most effective policies to meet these challenges [2]. Moreover, abundant sources of renewable energies worldwide hold promise for most countries, so governments are making efforts to develop them as safe fuels [3]. Fortunately, in recent years, researchers, policymakers and energy experts for renewable energy development around the world and especially in their countries have taken significant tangible actions [4].

For instance, Caferra et al. (2021) examined the critical role of political and social trust on energy-saving behaviour in Europe. Their results show that social and political 
trust positively impacts the reduction of domestic energy consumption, which has allowed people to save energy [5]. Neij et al. (2021), focusing on energy efficiency in buildings, investigated the transition of the energy system through evaluation of research, policy instruments and programmers in Sweden. Although the weakness of current evaluation practice is the limited scope and the fragmented approach does not support transformative change, they demonstrated using better vision documents for the envisioned transition. In addition, they strengthened coordination between evaluations can modify the current evaluation approach [6].

Frederiks et al. (2015) investigated conservation behaviour and the complexity of household energy consumption using psychology and behavioural economics principles. They proved that consumers, because of the wide gap between material interests, peoples' values and their actual behaviour, like to use more mental shortcuts to reduce this complexity and prefer lower-value certainties instead of higher-value risks. Furthermore, to ensure maximum return on investment and cost-effectiveness, they suggested more use of sustainable energy as an efficient strategy [7]. Finally, Sam Hampton et al. exanimated the role of the social sciences in environmental policy and influencing energy in the United Kingdom. Through interviews with government social researchers and auto-ethnographic insights working on climate change and the energy field, they discussed policy engagement for all energy researchers.

In this regard, they proved that government social researchers to incorporate practice theory into mainstream policy discourse need an evidence base for practice-inspired policy instruments that should take the help of the government social researchers scale (GSRS) [8]. Using cross-sectional data comprising answers, they investigated the willingness of the Netherlands people to expense money for sustainable energy development. Researchers demonstrated that hopeful people are willing to pay more for green energy expenses if their hope is not based on denial of the severity of the issue. The findings of this work, about the importance of climate change, could frame sustainability based on appropriate policies and measures for investing more green energy to tackle climate change [9]. Audley Genus et al. examined the implications of energy research and the transformation of energy systems as alternative energy concepts to meet energy challenges and climate change using a policy integration. They found that a techno-economic energy imagination still dominates European energy systems. The release needs a proper approach such as interdisciplinarity, attention to social practices relevant to energy use, and related knowledge with diverse actors. Also, the authors showed that the adoption of such an imaginary for enhancing policy integration of contribution of social sciences and humanities and ameliorating energy and climate change challenges is crucial [10].

Using the Westerlund and Edgerton technique, Muhammad Wasif Zafara et al. examined the positive role of technology, education in biomass energy consumption, and remarkable effects on environmental quality. In this research that belongs to Asia-Pacific Economic Cooperation countries, they proved that utilisation of biomass energy and technological innovation reduces the environmental quality, and growing economic increases carbon emissions in the environment. On the other hand, financial development and education contribute to reducing carbon emissions [11]. Mohammed Al-Breiki et al. evaluated the life cycle assessment of sustainable energy of various energy carriers including methanol, liquid hydrogen, liquefied natural gas, dimethyl ether, and liquid ammonia. They showed that Liquid hydrogen is produced from solar electrolysis with $42.50 \mathrm{~g} \mathrm{CO}_{2}$ eq among these energy sources. $\mathrm{MJ}^{-1}$ fuel) is the cleanest energy carrier. Also, the liquid ammonia produced through photovoltaic-based electrolysis with $60.76 \mathrm{~g} \mathrm{CO}_{2}$ eq. $\mathrm{MJ}^{-1}$ fuel), is cleaner than liquified natural gas [12]. Tomas Baležentis et al. explored the limits for increasing energy efficiency in the residential sector of the European Union. They investigated the rebound effect in the household sector based on the ODEX index and then proposed an econometric approach for estimation.

The results from 2000-2015 showed that the proposed approach as a reference and the other available approaches to ensure the robustness of the analysis can be applied. In this 
study and after using this method, countries such as Estonia, Italy, Slovenia, Spain, Bulgaria, Hungary, the Czech Republic, and Romania faced the most severe rebound effects, which led to backfire [13]. Yong Liu et al. examined unpacking stereotypes about sustainable energy. This study was conducted in China and was based on policy, knowledge, and public misperceptions regarding solar energy and coal. The results showed that negative stereotypes regarding these energy sources could lead to prejudice and misunderstandings and easily prevent sustainable energy development. From participants' point of view, solar energy was abundant, clean, and sustainable, but unreliable, costly, difficult to store, and regionally restricted. Also, participants believed that coal is unsustainable and a major source of pollution significant low prices and mature technology.

The survey results indicated that the participants' knowledge sources could easily influence stereotypes, thereby requiring some policies such as providing appropriate information, comparative thinking, and governmental promotion [14]. Bahareh Oryani et al. investigated the asymmetric impact of energy consumption on reshaping future energy policy in Iran. This work used the extended Cobb-Douglas production function, the oneway causality running from $\mathrm{EC}$ and $\mathrm{CO}_{2}$ emissions to GDP, and the symmetric impact of energy consumption on GDP was confirmed. To overcome the issues like economic growth, the authors recommended market-based and nonmarket-based interventions [15]. Based on evidence from common correlations, Festus Fatai Adedoyin et al. investigated alternative energy utilisation and its effects on low-carbon energy and trade on the environment from different perspectives.

Based on regional trade and the outlook of EU-27 alternative energy, this work demonstrated that alternative energy utilisation in the regional bloc aids, but regional trade policy could posit environmental issues in the EU [16]. Cody Yu-Ling Hsiao et al. examined the contagious effect of energy policy on stock markets for the solar photovoltaic industry in China by examining the fluctuations in the daily stock prices. Through both mean and volatility contagion channels, they showed that China's significant solar energy policies, including solar subsidies, feed-in tariffs, and market-based instruments, have remarkable effects on most sectors in China [17]. José Goldemberg et al. investigated the global demand for biofuels via sustainable land use in 2021. Due to the 2013 renewable energy policy mandates, Ethanol produced from sugarcane and corn in 2021 will need to increase from 80 to approximately 200 billion. Expansion of land into dedicated biofuels and increasing the productivity of raw material per hectare, or a combination of both, can reach this goal.

Therefore, a scientific basis and appropriate land expansion policies with environmental programs are essential for sustainable biofuel expansion [18]. This research highlights the existing subjectivities regarding governance actors perceiving and approaching citizens in different countries regarding the sustainable energy use transition. By drawing attention to the present epistemic and normative differences in different countries, we investigate the societal debate, citizen inclusion, local and national attempts to develop clear procedures and guidelines. The present study is based on energy policy insights for sustainable energy use, and in this regard, the theories, evidence, and policy implications are investigated for different countries.

It then presents effective strategies and policies to develop them. We analyze different sections to obtain appropriate results for the following researchers for better understanding and progress in their research works. This work can also be effective research researchers looking for relevant studies regarding sustainable energy use and development research. This research highlights the existing subjectivities regarding governance actors perceiving and approaching citizens in different countries regarding sustainable energy use transition. By drawing attention to the present epistemic and normative differences in different countries, we investigate the societal debate, citizen inclusion, local and national attempts to develop clear procedures and guidelines. 


\subsection{The Key Role of Social Context Citizens and Government in Social and Political Progresses}

Publics in societies are social representations of all citizens managed by actors in governance networks [19]. Therefore, it can be said that their participation and decisions significantly affect society, especially energy [20]. Now, if the public is active, uses knowledge, and has participated in different decisions, growth speed in society is accelerating by governance actors, and they achieve to welfare degree that expects [21]. Thereby, the previous public attitudes and behaviours essentially lead to the current and future formation of decisions by governments in society but are not absolute [22].

On the other hand, increasing the knowledge level of the public, and sudden public participation in has not happened in any society unless a vital issue or significant event has forced people to, increasing their knowledge level, participate and make public decisions [23]. So, expecting sudden growth in terms of intellectual and participatory from the general public is futile. However, it is possible to progress and sustain society by adopting strategies and approaches [24]. On the other hand, the role of governance and its power helps shape public expectations based on decision-making, and progress will evolve [25].

If the government, especially local governments, is kind, with plans, honesty, and compassion to people, this process will be faster, and vice versa [26]. In this regard, governments can encourage the public to change previous attitudes and behaviours around policy, technological requirements proposed, or new projects and help them make proper decisions on strategies, appropriate actions, and engagement formats [27].

\section{Elitist Approach by Governments and Key Role of Them in Society Progress}

From the logical point of view, the elite can be influential in different areas [28] and can present efficient suggestions in different times [29]. Thereby, elite rule and participation in making decisions are favourable for every society provided they are not abused [30]. Therefore, a remedial approach for governments and local governments to accelerate progress in different areas, especially in societies' transnational policy networks, is the use of elites to take responsibility and present practical solutions to overcome existing issues [31]. However, on the other hand, the elite knowledge about different fields of energy such as energy policy, energy efficiency, energy technology, sustainable energy, etc., especially for proposing appropriate solutions for overcoming challenges of global energy transformations on a more significant scale, can play a beneficial role [32]. In addition, about climate change issues [33], and energy (sustainable development) [34], renewable energy development [35], the elite using their thinking power can pave the way for policymakers and energy experts.

\subsection{Energy Technology: Introducing New Energy Systems for the Future}

Countries are under considerable pressure from the Paris agreement and are forced to reduce greenhouse gas emissions [36]. Therefore, they are intensely looking for new technology environmentally friendly solutions [37]. For this purpose, researchers and scientists in different fields but with the same goals such as energy efficiency [38], affordable energy [39], clean energy development [40], Blockchain technology and the sustainable supply chain [41], etc., that are for the welfare of humanity are working on the various systems and materials for introducing innovations applicable to energy systems [42].

In this regard, new technologies such as New Breed of Betavoltaics [43], Flexible Generators [44], Recycling Radio Waves [45], Pickin' Up Good Vibrations [46], Optical Rectenna [47], Fuel from the Sky [48], Graphene Supercaps [49], Monolithic Microscale Heat Pumps [50], and Next-gen Power Plants [51], are moving toward providing energy with $\mathrm{CO}_{2}$ emissions targets reduction [52], will be efficient and replacing with previous technologies in the future.

\subsubsection{Renewable Energy Development as Sustainable Energy}

The primary objective for deploying renewable energy in different countries is to advance economic development, improve access to energy, improve energy security, and 
mitigate climate change [53]. Therefore, the exploitation and development of renewable energy resources and technologies are critical for sustainable development [54]. At present, energy providers, based on price considerations, lack of consumers, sense of environmental and social responsibility, are trying to develop renewable energy that is encouraging [55]. Without a doubt, renewable energy has less negative environmental impact than other existing energy sources that we use [56].

Thereby, the reality that the utilisation of renewable energy in sustainable energy use is a logical and efficient way for policymakers and energy experts to achieve their targets, thus, they try to develop these kinds of energies as much as possible that so far have succeeded [57]. There are many countries where a considerable part of their energy is provided through renewable energy, expanding this plan [58]. The countries such as Germany [59], China [60], the US [61], Denmark [62], the UK [63] and European Union countries [64] are pioneer countries in this field. With an accurate glance at these countries' policies during these years, we will understand that all sections have developed renewable energy and widespread popular support for using renewable energy [65].

\subsubsection{The Government Policies in an Open Market for Supporting Clean Energy}

The positive effects of the government's policies in an open market for supporting clean energy have shown their trust in this kind of fuel [66]. Fortunately, in recent years the critical role of governments in the open market and appropriate policies to support particular generations such as renewables through allocating direct subsidies, feed-in tariffs, quota obligations were outstanding, tax relief. In addition, renewable portfolio standards and encouraging [67], especially in the US [68], China [69], and the EU [70], as the biggest energy producers in the world, were significant. Also, for giving more detail related to the EU, the European countries had remarkable plans for the energy subsidies during these years.

According to a report by the European parliament published 2020, energy subsidies can be in various forms, such as government revenue foregone (e.g., tax incentives and credits), the direct transfer of funds (e.g., grants, loans), the provision of goods and services, price support, payments to funding mechanisms, or income. In this regard, it reported that total energy subsidies in the European countries in 2018 were estimated at EUR159 billion. As above mentioned, the forms of subsidies in EU countries are different. For instance, two-thirds of Germany's total volume of subsidies supported renewables, while primarily in Latvia supported energy efficiency measures. In addition, In Greece, France, Finland, Belgium, Poland, and Ireland, the highest shares were spent on fossil fuels. This report also showed that most of the subsidies, respectively, belonged to the energy sector (EUR92 billion), industry (EUR20 billion), households (EUR17 billion), transport (EUR13 billion), and in the end in agriculture (EUR5 billion) in 2018, that renewable energy in the energy sector, received almost three-quarters of the subsidies.

Thus, this report demonstrated the importance of renewable subsidies in the energy sector in supporting their deployment [71]. Moreover, the government's policies to allocate direct subsidies and tariffs on renewable energy for developing the markets in countries show that the governments of these countries have unique plans for more rely on renewable energy as the main fuel in the future, such as Italy [72], Iran [73], Australia [74], Netherland [75], Saudi Arabia [76], Sweden [77], Brazil [78], Chile [79], and Canada [80].

\section{Materials and Methods}

Interventional studies involving animals or humans, and other studies that require ethical approval, must list the authority that provided approval and the corresponding ethical approval code. Investigating behavioural insights for sustainable energy use requires comprehensive research in the different fields of energy. As such, the role of government, policymakers, energy experts, local governments, and people is significant. In this research and in order to collect the information required, we used the words such as sustainable energy use, energy policy, governments and planning for sustainable energy use, policies 
for energy system in different countries, the critical role of local and the role of the national government in sustainable energy through databases such as, Google Scholar, Scopus, Web of Science. Then, based on their accessibility of the articles, and eligibility criteria, we during two years, have examined and identified an exhaustive review of more than 1000 relevant publications and scientific reports related to energy systems such as the European Commission (EC), european energy reports, and science report, etc.

After collecting information and evaluating the articles collected based on titles, abstracts, and introductions, we selected 170 articles among them. Next, we did two stages in parallel; (a) review articles and reports to have a global understanding of energy systems development to find the appropriate solutions to overcome related problems. These helped us improve our background and knowledge for writing this work. (b) reviewing technical papers for identifying appropriate policies and defining the correct pathway for this research. Eventually, we have analyzed and obtained the relevant results based on the information of these studies. Figure 1 shows the methodology flowchart.

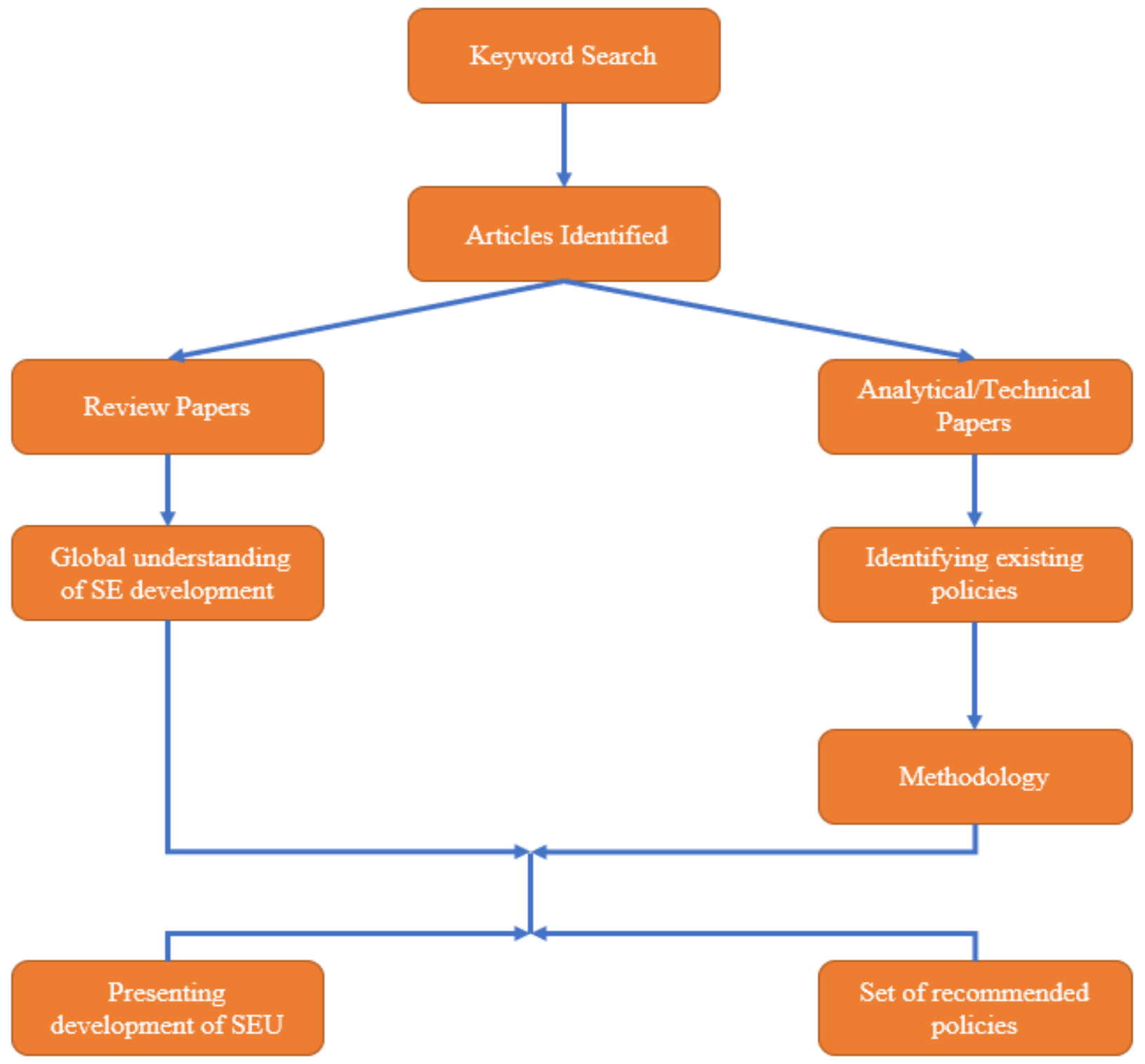

Figure 1. The methodology flowchart. 


\section{Results}

In this section, we investigate that for understanding governance to more sustainable energy use, the essential actor groups, their relationship to governance, and their interests. On the other hand, we investigate the politics of the governing about sustainable energy use, their arguments, and relevant them mediated by political institutions.

\subsection{Initiatives Governments for Sustainable Energy Use and Green Deal in Different Countries}

Undoubtedly, there need to be profound practice changes for establishing sustainable energy, especially in energy policy and prospects for different countries. However, this is not easy but should be done [81]. The changes such as regulation in energy consumption [82], how energy is produced and used energy technology [83], and energy price should be done by policymakers as the most important initiatives of the governments in the line of sustainable energy [84]. Government initiatives and their responsibilisation have caused those numerous projects in the sphere of green energy.

Because of this, and in recent years, the countries such as Argentina, Brazil, Canada, Mexico, and the United States for green energy proliferation and with economic benefits, and $\mathrm{CO}_{2}$ emission reduction targets, have spent much money through its policy. However, government initiatives are always inefficient for countries because most projects will fail without planning and energy policy. Therefore, the correct understanding of the governments of current situations and how a national project can succeed is critical by using policymakers and energy experts plans well done [85]. Therefore, it can be concluded that policymakers and energy experts have a critical and active role in shaping energy policy at the high level of governments energy governance. They can use effective strategies and policies to shape the energy systems (sustainable energy) in the line of stakeholders [86].

For example, in the US, and the UK, measures such as the Energy Company Obligation and Green Deal, for encouraging energy efficiency innovations while were slow to start, now represent ambitious efforts of these countries to drive domestic retrofit markets. It shows that new sustainable energy policies can make regulations and rules that increase sustainable practices however are under governance processes [87]. Also, Luciana Maria Miu et al. explored large-scale retrofit of UK housing based on domestic energy efficiency and emissions reduction targets. The authors used a straightforward assessment framework, assessed Green Mortgage, the Variable Stamp Duty Land Tax, and the Variable Council Tax known for the Energy Company Obligation (ECO) to replace the UK's current major domestic retrofit proposed. They showed that the green Mortgage and the Variable Council Tax for overcoming the main barriers to retrofit policies have a high potential for the high-level UK targets, especially energy consumption [88]. About this reality that still there is a significant financing gap like an investment for the large-scale deployment of low-carbon technologies in different countries. Through 52 interviews in three countries (Germany, Australia, and the UK), investment banks' performance is to leverage additional private finance and close this finance gap in these countries.

The results showed that the Kreditanstalt fur Wiederaufbau (KfW) in Germany, the Clean Energy Finance Corporation (CEFC) in Australia, and the Green Investment Bank (GIB) in the UK are proper for these targets. Because these banks can create trust for projects, help projects gain an excellent track record and enable financial sector learning in catalyzing private investments into low-carbon investments [89]. The European green Deal examined the emission performance standards and the perspectives. This Commission approved that car manufacture between 2021 and 2030 must reduce 37.5\% of the average carbon emissions of their fleets. This action was crucial for mobility research to reduce lobbying power in the EU and led to more moving to electric vehicles [90]. In order to minimise the domestic energy use in cities in achieving sustainability goals, Gary Goggins et al., with an analysis of a database of 249 recent sustainable energy initiatives across urban areas in Europe, evaluated two major themes, namely stratification and integration that emerged from reviewing the data. 
They recognised for stratification five key areas: governance, general approach, evaluation frameworks, problem framing, and engagement mechanisms. Moreover, for the corresponding typology of initiatives, four categories: experimental, enhancing, responsive, and directional have been recognised. Then they argued that integration of these initiatives could increase the success of initiatives in household energy use to achieve long-term sustainable transformation across critical areas [91]. Finally, four municipalities of Norway and Sweden investigated central government ambitions and local commitment to climate mitigation initiatives. In this study, they showed that the national approaches for developing such initiatives depend not only on the central government efforts but also on the targeted municipalities. In this regard, local coalitions of committed individuals for helping the government programs and implement these initiatives are significant [92].

\subsection{The Effect of Policy and Regulatory Framework Initiatives}

Without a doubt, the effect of policy and regulatory framework initiatives is impressive on society. Therefore, this regard needs accurate energy planning, practical strategies, policies calculated by policy-makers and energy experts, recognising issues and solutions for these. [93]. The actions such as Tariff policy amendments [94], encouraging investors to come to energy markets [95], full support of the equipment failure [96], forecasting natural disasters to prevent damages, and tackle potential hazards in relation with energy [97], issued the standardisation of renewable energy projects policy (testing, standardisation, and certification) [98], action plans for standards (testing and certification of performance) for renewable energy [99], improvement of manufactured components of the energy systems [100], improvement and co-optimisation of the infrastructure of energy systems [101], developing markets of renewable energy [102], finding main barriers of energy systems [103], review mechanism of energy efficiency policies especially for buildings [104], critical revisions energy efficiency policies [105], reduce the subsidies and invest in Research \& Development Funding (R\&D) lagging [106], increasing manufacturing storage system affordable to reduce the cost of renewables [107], and renewable energy technologies development [108], can be efficient as proper policy and regulatory framework initiatives by governments in sustainable energy use development.

\subsection{Strategies and New Approaches for Behaviour Change of People}

Human activities affect atmospheric composition and energy consumption [109] directly. Moreover, these adverse effects cause issues such as global warming and energy crisis [110]. In addition, lack of energy, especially electricity, will cancel most activities in the different countries; therefore, developing energy with a low-carbon policy is essential for every country [111]. On the other hand, as energy is an auxiliary good for increasing life, it requires accurate consumption monitoring, especially for domestic appliances, electronics, etc. [112]. Energy consumption at home and work, rather than on deliberate choices, is based on automatic and routine behaviour [113]. Then, to have electricity permanently as the essential kind of energy and its conserve, we should not be wasting so much electricity quickly when we do not need it [114]. Thereby, behaviour change programs to use less energy can be effective, especially in their homes [115]. Behaviour changes of people in energy use at home and at work on evidence from behavioural psychology and economics shows that the new approaches can convince people to reduce energy consumption and prevent loss of energy easily [116].

Based on routine reporting of comparative energy consumption information in-home, and work adopting strategies like behaviour change programmes advice can have remarkable effects in reductions in energy use and lead to energy savings [117]. In this regard, having essential strategies, governments, and policymakers' strategies such as energy technologies (Smart meters) for improving energy efficiency and reducing energy consumption should be considered [118]. On the other hand, paying attention to enhancing people's sufficiency can be investigated as an efficient strategy [119]. Because when the people know how energy is produced and what issues before producing it, they will know the 
energy's value [120]. However, sometimes, due to financial incentives, the people don't like to follow up the policies of the governments in the energy consumption field. Thereby, they refusal the regulations [121]. The intervening of governments to change behaviour and save energy is effective such as, more training [122], presenting cost-effective, mass-scalable behavioural solutions to encourage renewable and sustainable energy use among consumers [123], greater control to employees and organisations [124], implanting the smart meter systems in offices and homes [125], considering a penalty [126], and implanting price tags and energy efficiency labels on the high consumer's electrical devices [127], for the people that have not attended to their consumption.

\subsection{Applying Psychology and Behavioural Economics to Explain, Predict and Change Consumer Behavior}

One of the most critical issues about energy is consumer behaviour [128]. Consumer behaviour analysis such as behavioural psychology, behavioural economics, and marketing science is essential to finding hidden issues related to energy [129]. For example, Foxall, G. R. during the years 2004, 2010, 2011, 2015, and 2016, investigated consumer psychology from a behavioural perspective and showed people's behavior in different times depending on the situation, is related to the norms of economic theory [130-134]. However, Kahneman and Tversky have demonstrated that people's behavior often deviates substantially from the norms of economic theory [135]. Moreover, Nils Magne Larsen believes that another technique for consumer research is in-store observation of the consumers in stores Behavior based on their choices [136]. Michael G. Pollitt et al., proved that behavioural economics could provide new positive perspectives, lead to appropriate policy design for change behaviour, evaluate options, and make correct decisions to tackle climate change while considering energy efficiency and conservation [137]. N'Famory Camara et al., using behavioural economics, examined the understanding of household energy use and decision making and in Guinea-Conakry.

They showed that concerning an increase in power generation, behavioural economics could predict consumer behaviour before the projects' full completion and prevent the public policy interventions of the household and community [138]. Elizabeth V. Hobman et al. investigated uptake and usage of cost-reflective electricity pricing in Australia. This work presents the psychology and behavioural economics insights to design cost-reflective prices for customers for their attracts and optimal usage for most of the population. These works showed that having proper strategies about behavioural economics has a significant role in energy consumption management while providing shared benefits for customers, networks, retailers, and regulators alike [139].

Finally, Luis Mundaca et al. examined the behavioural economics for Scandinavian perspective energy based on the transition to sustainable energy use and climate change policies. Regarding the critical role of behavioural economics on decarbonisation activities and sustainable energy, they showed that policy evaluation, design, and implementation, need to be given greater attention to behavioural issues. On the other hand, they proved that behavioural interventions for sustainable energy use are not enough; price and nonprice interventions also are required, like the technological policymaking approach [140].

\subsection{Obstacles in Sustainable Energy Development}

For developing sustainable energy use, paying attention to obstacles and finding solutions for them is significant. Thereby, we divided the obstacles into three essential parts observed in Table 1. These include (1) education and training obstacles, (2) environmental obstacles, (3) Social, Economy and policy obstacles. 
Table 1. Obstacles and solutions in sustainable energy development.

\begin{tabular}{|c|c|c|}
\hline Type of the Obstacles & Obstacles & References \\
\hline Education and training & $\begin{array}{l}\text { Lack of skilled human resources especially in the renewable energy } \\
\text { sector. Weak follow-up or assistance for the workers (especially } \\
\text { during the projects). Weak knowledge in renewables. Lack of } \\
\text { awareness programs for the general public, Low per capita income. } \\
\text { Lack of trust in the storage system because too costly. Lack clearly } \\
\text { understood for the environmental benefits of renewable } \\
\text { technologies by the people. }\end{array}$ & [141-146] \\
\hline Environmental & $\begin{array}{l}\text { Great dangers of the thin-film PV cells in increasing the public } \\
\text { health threats and environmental threats. The massive volume of } \\
\text { wind turbines whatever offshore or onshore, and underwater blade } \\
\text { (effect on roads and transmission lines, fishing, sand extraction, } \\
\text { gravel extraction, oil extraction, gas extraction, aquaculture, fish, } \\
\text { algae, aquatic weeds and other organisms, and navigation of the } \\
\text { birds and bats. Adverse effects of Sound and visual impacts of } \\
\text { wind turbines. The wind turbines' adverse effects (material } \\
\text { production, transportation of materials, on-site construction, } \\
\text { assembling, operation, maintenance, dismantlement) and improper } \\
\text { disposal of their wastes. }\end{array}$ & [147-158] \\
\hline Social, economy and policy & $\begin{array}{l}\text { Lack of investment or low investment. Lack Tariff of governments } \\
\text { for people. Lack of enough training. Lack acceptance quickly by } \\
\text { people. Weak in the feedstock market. Weak legislation, policies } \\
\text { development, deforestation, inefficient energy-saving systems, } \\
\text { inefficient conservative scenarios of governments. Also, obtain an } \\
\text { accurate picture of the local current energy situation, measure the } \\
\text { state of development and the progress of sustainable energy system, } \\
\text { and make energy decisions to implications on sustainable } \\
\text { development of selected policies, especially in Africa countries. } \\
\text { Access to affordable and accessible electricity concerning UN SDG7 } \\
\text { by using clean energy. }\end{array}$ & [159-170] \\
\hline
\end{tabular}

\section{Conclusions}

Concerning environmental issues and energy crises, sustainable energy use and development is one of the most critical targets of each country. In this research, regarding the present epistemic and normative differences in different countries, we investigated the societal debate regarding citizen inclusion and local and national attempts to develop clear procedures and guidelines in the sustainable energy use transition line. The present study was based on energy policy insights for sustainable energy use. In this regard, the theories, evidence existing subjectivities, and policy implications are explored for different countries. The study presents a comprehensive review of the previous studies concerning previous and current research in sustainable energy use. It then presents effective strategies and policies to develop them. This conceptual work offers a new, interdisciplinary framework for analyzing governing, people, institutions, and organizations for sustainable energy systems by drawing together insights from and offering critiques of socio-technical transitions and new institutionalist concepts of change.

This work can be attended as effective research to researchers looking to relevant studies regarding sustainable energy use and development research. This research highlighted the existing subjectivities regarding governance actors perceiving and approaching citizens in different countries regarding sustainable energy use transition. The results showed that the role of policy is significant in renewable technologies development, attracting private investors, improving energy infrastructures, managing energy consumption, encouraging and punishing the offices and people who lose energy. However, in this regard, there are issues inherent in lack of sustainable energy use; others are the outcome of a skewed regulative structure and marketplace. Hence, the absence of appropriate and comprehensive 
policies and regulation frameworks prevents people from adopting sustainable energy use, and sustainable energy development requires explicit policies and proper approaches.

Author Contributions: Conceptualisation, A.R.; Investigation, Visualization, Data curation, writing and methodology, A.R., M.R., S.M. and M.M.N.; Investigation, A.R. and M.M.N.; Resources, Formal analysis, A.R., M.R., S.M., M.M.N. and G.P.; Writing-review and editing, A.R. and M.M.N.; Supervision, G.P. All authors have read and agreed to the published version of the manuscript.

Funding: This research received no external funding.

Institutional Review Board Statement: Not applicable.

Informed Consent Statement: Not applicable.

Data Availability Statement: Not applicable.

Conflicts of Interest: The authors declare no conflict of interest.

\section{References}

1. Heydari, A.; Astiaso Garcia, D.; Keynia, F.; Bisegna, F.; de Santoli, L. Hybrid intelligent strategy for multifactor influenced electrical energy consumption forecasting. Energy Sources Part B Econ. Plan. Policy 2019, 14, 341-358. [CrossRef]

2. Razmjoo, A. Effective policies to overcome barriers in the development of smart cities. Energy Res. Soc. Sci. 2021, $79,102175$. [CrossRef]

3. Meadowcroft, J. Engaging with the politics of sustainability transitions. Environ. Innov. Soc. Transit. 2011, 1, 70-75. [CrossRef]

4. Razmjoo, A. Development of sustainable energy indexes by the utilization of new indicators: A comparative study. Energy Rep. 2019, 5, 375-383. [CrossRef]

5. Caferra, R.; Colasante, A.; Morone, A. The less you burn, the more we earn: The role of social and political trust on energy-saving behaviour in Europe. Energy Res. Soc. Sci. 2021, 71, 101812. [CrossRef]

6. Neij, L.; Sandin, S.; Benner, M.; Johansson, M.; Mickwitz, P. Bolstering a transition for a more sustainable energy system: A transformative approach to evaluations of energy efficiency in buildings. Energy Res. Soc. Sci. 2021, 72, 101864. [CrossRef]

7. Frederiks, E.R.; Stenner, K.; Hobman, E.V. Household energy use: Applying behavioural economics to understand consumer decision-making and behaviour. Renew. Sustain. Energy Rev. 2015, 41, 1385-1394. [CrossRef]

8. Hampton, S.; Adams, R. Behavioural economics vs social practice theory: Perspectives from inside the United Kingdom government. Energy Res. Soc. Sci. 2018, 46, 214-224. [CrossRef]

9. Pleeging, E.; van Exel, J.; Burger, M.J.; Stavropoulos, S. Hope for the future and willingness to pay for sustainable energy. Ecol. Econ. 2021, 181, 106900. [CrossRef]

10. Genus, A.; Iskandarova, M.; Goggins, G.; Fahy, F.; Laakso, S. Alternative energy imaginaries: Implications for energy research, policy integration and the transformation of energy systems. Energy Res. Soc. Sci. 2021, 73, 101898. [CrossRef]

11. Zafar, M.W.; Sinha, A.; Ahmed, Z.; Qin, Q.; Zaidi, S.A.H. Effects of biomass energy consumption on environmental quality: The role of education and technology in Asia-Pacific Economic Cooperation countries. Renew. Sustain. Energy Rev. 2021, 142, 110868. [CrossRef]

12. Al-Breiki, M.; Bicer, Y. Comparative life cycle assessment of sustainable energy carriers including production, storage, overseas transport and utilization. J. Clean. Prod. 2021, 279, 123481. [CrossRef]

13. Baležentis, T.; Butkus, M.; Štreimikienè, D.; Shen, Z. Exploring the limits for increasing energy efficiency in the residential sector of the European Union: Insights from the rebound effect. Energy Policy 2021, 149, 112063. [CrossRef]

14. Liu, Y.; Zhang, M. Unpacking stereotypes about sustainable energy: Knowledge, policy, and public misperceptions of solar energy and coal in China. Energy Res. Soc. Sci. 2021, 71, 101832. [CrossRef]

15. Oryani, B.; Koo, Y.; Rezania, S.; Shafiee, A. Investigating the asymmetric impact of energy consumption on reshaping future energy policy and economic growth in Iran using extended Cobb-Douglas production function. Energy 2021, $216,119187$. [CrossRef]

16. Adedoyin, F.F.; Alola, A.A.; Bekun, F.V. The alternative energy utilization and common regional trade outlook in EU-27: Evidence from common correlated effects. Renew. Sustain. Energy Rev. 2021, 145, 111092. [CrossRef]

17. Hsiao, C.Y.-L.; Ai, D.; Wei, X.; Sheng, N. The contagious effect of China's energy policy on stock markets: The case of the solar photovoltaic industry. Renew. Energy 2021, 164, 74-86. [CrossRef]

18. Goldemberg, J.; Mello, F.F.; Cerri, C.E.; Davies, C.A. Meeting the global demand for biofuels in 2021 through sustainable land use change policy. Energy Policy 2014, 69, 14-18. [CrossRef]

19. Castells, M. The New Public Sphere: Global Civil Society, Communication Networks, and Global Governance. Ann. Am. Acad. Politi. Soc. Sci. 2008, 616, 78-93. [CrossRef]

20. Rodhouse, T.; Pesch, U.; Cuppen, E.; Correljé, A. Public agency and responsibility in energy governance: A Q study on diverse imagined publics in the Dutch heat transition. Energy Res. Soc. Sci. 2021, 77, 102046. [CrossRef] 
21. Kostka, G. China's social credit systems and public opinion: Explaining high levels of approval. New Media Soc. 2019, 21, 1565-1593. [CrossRef]

22. Kaffashi, S.; Shamsudin, M.N. Transforming to a low carbon society; an extended theory of planned behaviour of Malaysian citizens. J. Clean. Prod. 2019, 235, 1255-1264. [CrossRef]

23. Geoff, M. Social Innovation: How Societies Find the Power to Change. Int. Rev. Appl. Econ. 2019, 34, 691-696. [CrossRef]

24. Ziemba, E. The Contribution of ICT Adoption to the Sustainable Information Society. J. Comput. Inf. Syst. 2019, 59, 116-126. [CrossRef]

25. An, B.Y. What Determines Where Public Investment Goes? Regional Governance and the Role of Institutional Rules and Power. Available online: https:/ / onlinelibrary.wiley.com/doi/epdf/10.1111/puar.13220 (accessed on 15 January 2021).

26. Long, L.A.N.; Krause, R.M. Managing policy-making in the local climate governance landscape: The role of network administrative organizations and member cities. Public Adm. 2021, 99, 23-39. [CrossRef]

27. Lokaimoe, P.; Bartocho, E.; Omillo, F. Refocusing Public Participation for a New Management Era in Kenya: Insights from Literature. Afr. J. Educ. Sci. Technol. 2012, 6, 24-39. Available online: http://ajest.info/index.php/ajest/article/view/494 (accessed on 30 November 2021).

28. Hong, M.S.; Chun, Y.J. Symbolic habitus and new aspirations of higher education elites in transitional Myanmar. Asia Pac. Educ. Rev. 2021, 22, 67-76. [CrossRef]

29. Ashineh, M. Social Capital and Development in Hormozgan Province from the Perspective of the Elites. Int. J. Soc. Sci. 2021, $11,81-96$.

30. Messamore, A. The civic elite: A network perspective on elite consolidation among community-based organizations, 1998-2016. Soc. Netw. 2021, 66, 146-160. [CrossRef]

31. Henriksen, L.F.; Seabrooke, L. Elites in transnational policy networks. Glob. Netw. 2021, 21, 217-237. [CrossRef]

32. Parker, C. Energy transition in South America: Elite's views in the mining sector, four cases under study. Ambiente Soc. 2018, 21. [CrossRef]

33. Van Boven, L.; Sherman, D.K. Elite influence on public attitudes about climate policy. Curr. Opin. Behav. Sci. 2021, 42, 83-88. [CrossRef]

34. Ahvenharju, S. Acceptability of radical consumption policies-Utilising futures consciousness to understand elite preferences. Futures 2021, 128, 102711. [CrossRef]

35. Smeets, N. The Green Menace: Unraveling Russia's elite discourse on enabling and constraining factors of renewable energy policies. Energy Res. Soc. Sci. 2018, 40, 244-256. [CrossRef]

36. Falkner, R. The Paris Agreement and the new logic of international climate politics. Int. Aff. 2016, 92, 1107-1125. [CrossRef]

37. Wang, Y. Research on All-Vanadium Redox Flow Battery Energy Storage Device Based on Energy-Saving and EnvironmentallyFriendly New Energy Power Station Interface. IOP Conf. Ser. Earth Environ. Sci. 2021, 651, 022097. [CrossRef]

38. Brugger, H.; Eichhammer, W.; Mikova, N.; Dönitz, E. Energy Efficiency Vision 2050: How will new societal trends influence future energy demand in the European countries? Energy Policy 2021, 152, 112216. [CrossRef]

39. Razmjoo, A Technical analysis investigating energy sustainability utilizing reliable renewable energy sources to reduce $\mathrm{CO}_{2}$ emissions in a high potential area. Renew. Energy 2021, 164, 46-57. [CrossRef]

40. Nwozor, A.; Oshewolo, S.; Owoeye, G.; Okidu, O. Nigeria's quest for alternative clean energy development: A cobweb of opportunities, pitfalls and multiple dilemmas. Energy Policy 2021, 149, 112070. [CrossRef]

41. Hoicka, C.E.; Das, R.R.; Zhao, Y.; McMaster, M.-L.; Lieu, J.; Wyse, S. Methodology to identify demand-side low-carbon innovations and their potential impact on socio-technical energy systems. MethodsX 2021, 8, 101295. [CrossRef]

42. Kouhizadeh, M. Blockchain technology and the sustainable supply chain: Theoretically exploring adoption barriers. Int. J. Prod. Econ. 2021, 231, 107831. [CrossRef]

43. Clarke, D.P.; Al-Abdeli, Y.; Kothapalli, G. Multi-objective optimisation of renewable hybrid energy systems with desalination. Energy 2015, 88, 457-468. [CrossRef]

44. Jeng, Y.-R.; Mendy, A.; Ko, C.-T.; Tseng, S.-F.; Yang, C.-R. Development of Flexible Triboelectric Generators Based on Patterned Conductive Textile and PDMS Layers. Energies 2021, 14, 1391. [CrossRef]

45. Lan, C. A wind-induced negative damping method to achieve high-energy orbit of a nonlinear vibration energy harvester. Smart Mater. Struct. 2021, 30, 02LT02. [CrossRef]

46. Yinger, R.; Kamiab, A. Good Vibrations. IEEE Power Energy Mag. 2011, 9, 22-32. [CrossRef]

47. Kanaujia, B.K.; Singh, N.; Kumar, S. Background and Origin of the Rectenna. In Rectenna: Wireless Energy Harvesting System. Advances in Sustainability Science and Technology; Springer: Singapore, 2021. [CrossRef]

48. Suresh, L.; Vaghasiya, J.V.; Kannan, U.P.; Zhang, Y.; Ravi, S.K.; Paul, N.; Jones, M.R.; Tan, S.C. 1200\% enhancement of solar energy conversion by engineering three dimensional arrays of flexible biophotoelectrochemical cells in a fixed footprint encompassed by Johnson solid shaped optical well. Nano Energy 2021, 79, 105424. [CrossRef]

49. Krishnamoorthy, K.; Pazhamalai, P.; Mariappan, V.K.; Manoharan, S.; Kesavan, D.; Kim, S. Two-Dimensional Siloxene-Graphene Heterostructure-Based High-Performance Supercapacitor for Capturing Regenerative Braking Energy in Electric Vehicles. Adv. Funct. Mater. 2021, 31, 2008422. [CrossRef]

50. Determan, M.D.; Garimella, S. Design, fabrication, and experimental demonstration of a microscale monolithic modular absorption heat pump. Appl. Therm. Eng. 2012, 47, 119-125. [CrossRef] 
51. Oudes, D.; Stremke, S. Next generation solar power plants? A comparative analysis of frontrunner solar landscapes in Europe. Renew. Sustain. Energy Rev. 2021, 145, 111101. [CrossRef]

52. Pata, U.K. Linking renewable energy, globalization, agriculture, $\mathrm{CO}_{2}$ emissions and ecological footprint in BRIC countries: A sustainability perspective. Renew. Energy 2021, 173, 197-208. [CrossRef]

53. Kumar, J.C.R.; Majid, M.A. Renewable energy for sustainable development in India: Current status, future prospects, challenges, employment, and investment opportunities. Energy Sustain. Soc. 2020, 10, 2. [CrossRef]

54. Hao, F.; Shao, W. What really drives the deployment of renewable energy? A global assessment of 118 countries. Energy Res. Soc. Sci. 2021, 72, 101880. [CrossRef]

55. Kasaeian, A. Deployment of a stand-alone hybrid renewable energy system in coastal areas as a reliable energy source. Environ Prog. Sustain. Energy 2020, 39, e3354. [CrossRef]

56. Chen, C. Determinants of renewable energy consumption: Importance of democratic institutions. Renew. Energy 2021, 179, 75-83. [CrossRef]

57. Østergaard, P.A.; Duic, N.; Noorollahi, Y.; Mikulcic, H.; Kalogirou, S. Sustainable development using renewable energy technology. Renew. Energy 2020, 146, 2430-2437. [CrossRef]

58. Bórawski, P.; Bełdycka-Bórawska, A.; Szymańska, E.; Jankowski, K.J.; Dubis, B.; Dunn, J.W. Development of renewable energy sources market and biofuels in The European Union. J. Clean. Prod. 2019, 228, 467-484. [CrossRef]

59. Dehler-Holland, J.; Schumacher, K.; Fichtner, W. Topic Modeling Uncovers Shifts in Media Framing of the German Renewable Energy Act. Gene Expr. Patterns 2021, 2, 100169. [CrossRef]

60. Yu, S.; Hu, X.; Li, L.; Chen, H. Does the development of renewable energy promote carbon reduction? Evidence from Chinese provinces. J. Environ. Manag. 2020, 268, 110634. [CrossRef]

61. Alola, A.A.; Akadiri, S.S. Clean energy development in the United States amidst augmented socioeconomic aspects and countryspecific policies. Renew. Energy 2021, 169, 221-230. [CrossRef]

62. Andresen, G.B.; Søndergaard, A.A.; Greiner, M. Validation of Danish wind time series from a new global renewable energy atlas for energy system analysis. Energy 2015, 93, 1074-1088. [CrossRef]

63. Ojo, A.A. An Overview of the Exploitation of Renewable Energy Resources in Nigeria, South Africa, and the United Kingdom. Int. J. Energy Res. 2020, 10, 843-861.

64. Quintana-Rojo, C.; Callejas-Albiñana, F.-E.; Tarancón, M.Á.; Martínez-Rodríguez, I. Econometric Studies on the Development of Renewable Energy Sources to Support the European Union 2020-2030 Climate and Energy Framework: A Critical Appraisal. Sustainability 2020, 12, 4828. [CrossRef]

65. Kuzemko, C.; Britton, J. Policy, politics and materiality across scales: A framework for understanding local government sustainable energy capacity applied in England. Energy Res. Soc. Sci. 2020, 62, 101367. [CrossRef]

66. Shao, X.; Fang, T. Performance analysis of government subsidies for photovoltaic industry: Based on spatial econometric model. Energy Strat. Rev. 2021, 34, 100631. [CrossRef]

67. Dahlke, S. Chapter 12-Policy and market drivers for advancing clean energy. Adv. Clean Energy Technol. 2021, 12, 451-485. [CrossRef]

68. Shayegh, S.; Sanchez, D.L. Impact of market design on cost-effectiveness of renewable portfolio standards. Renew. Sustain. Energy Rev. 2021, 136, 110397. [CrossRef]

69. Yang, X.J.; Hu, H.; Tan, T.; Li, J. China's renewable energy goals by 2050. Environ. Dev. 2016, 20, 83-90. [CrossRef]

70. Boasson, E.L.; Leiren, M.D.; Wettestad, J. Europeanization of Renewables Support, Comparative Renewables Policy. 2021. Available online: https:/ / library.oapen.org/handle/20.500.12657/41705 (accessed on 30 November 2021).

71. Report to the European Parliament, the Council, the European Economic and Social Committee and the Committee of the Regions. Available online: https:/ / ec.europa.eu/energy/sites/ener/files/progress_on_energy_subsidies_in_particular_for_fossil_fuels. pdf (accessed on 30 November 2021).

72. Clò, S.; Cataldi, A.; Zoppoli, P. The merit-order effect in the Italian power market: The impact of solar and wind generation on national wholesale electricity prices. Energy Policy 2015, 77, 79-88. [CrossRef]

73. Solaymani, S. Energy subsidy reform evaluation research-Reviews in Iran. Greenh. Gases Sci. Technol. 2021, 11, 520-538. [CrossRef]

74. Kuwahata, R.; Monroy, C.R. Market stimulation of renewable-based power generation in Australia. Renew. Sustain. Energy Rev. 2010, 15, 534-543. [CrossRef]

75. Inês, C.; Guilherme, P.L.; Esther, M.-G.; Swantje, G.; Stephen, H.; Lars, H. Regulatory challenges and opportunities for collective renewable energy prosumers in the EU. Energy Policy 2020, 138, 111212. [CrossRef]

76. Ramli, M.A.M.; Twaha, S. Analysis of renewable energy feed-in tariffs in selected regions of the globe: Lessons for Saudi Arabia. Renew. Sustain. Energy Rev. 2015, 45, 649-661. [CrossRef]

77. Tarkowski, M. Towards a More Sustainable Transport Future-The Cases of Ferry Shipping Electrification in Denmark, Netherland, Norway and Sweden. In Innovations and Traditions for Sustainable Development; Leal Filho, W., Krasnov, E.V., Gaeva, D.V., Eds.; World Sustainability Series; Springer: Cham, Switzerland, 2021. [CrossRef]

78. Mitscher, M.; Ruther, R. Economic performance and policies for grid-connected residential solar photovoltaic systems in Brazil. Energy Policy 2012, 49, 688-694. [CrossRef] 
79. Nasirov, S.; Silva, C.A.S.; Agostini, C.A. Investors' Perspectives on Barriers to the Deployment of Renewable Energy Sources in Chile. Energies 2015, 8, 3794-3814. [CrossRef]

80. Marie, W. Feed-In Tariffs for Renewable Energy and WTO Subsidy Rules: An Initial Legal Review (30 August 2011). In Marie Wilke, Feed-In Tariffs for Renewable Energy and WTO Subsidy Rules: An Initial Legal Review; ICTSD International Centre for Trade and Sustainable Development: Geneva, Switzerland, 2011; Volume 4. Available online: https:/ / ssrn.com/abstract=1919517. (accessed on 30 November 2021).

81. Frank, G. Reducing energy demand through low carbon innovation: A sociotechnical transitions perspective and thirteen research debates. Energy Res. Soc. Sci. 2018, 40, 23-35. [CrossRef]

82. Sun, L.; Zhang, T.; Liu, S.; Wang, K.; Rogers, T.; Yao, L.; Zhao, P. Reducing energy consumption and pollution in the urban transportation sector: A review of policies and regulations in Beijing. J. Clean. Prod. 2021, 285, 125339. [CrossRef]

83. Díaz-Herrera, P.R.; Ascanio, G.; Romero-Martínez, A.; Alcaraz-Calderón, A.M.; González-Díaz, A. Theoretical comparison between post-combustion carbon capture technology and the use of blue and green $\mathrm{H}_{2}$ in existing natural gas combined cycles as $\mathrm{CO}_{2}$ mitigation strategies: A study under the context of Mexican clean energy regulation. Int. J. Hydrogen Energy 2021, 46, 2729-2754. [CrossRef]

84. Wang, R.; Hsu, S.-C.; Zheng, S.; Chen, J.-H.; Li, X.I. Renewable energy microgrids: Economic evaluation and decision making for government policies to contribute to affordable and clean energy. Appl. Energy 2020, 274, 115287. [CrossRef]

85. Pischke, E.C.; Solomon, B.; Wellstead, A.; Acevedo, A.; Eastmond, A.; De Oliveira, F.; Coelho, S.; Lucon, O. From Kyoto to Paris: Measuring renewable energy policy regimes in Argentina, Brazil, Canada, Mexico and the United States. Energy Res. Soc. Sci. 2019, 50, 82-91. [CrossRef]

86. Albrecht, M. Translating bioenergy policy in Europe: Mutation, aims and boosterism in EU energy governance. Geoforum 2017, 87, 73-84. [CrossRef]

87. Gillich, A.; Sunikka-Blank, M.; Ford, A. Lessons for the UK Green Deal from the US BBNP. Build. Res. Inf. 2016, 45, 384-395. [CrossRef]

88. Miu, L.M.; Wisniewska, N.; Mazur, C.; Hardy, J.; Hawkes, A. A Simple Assessment of Housing Retrofit Policies for the UK: What Should Succeed the Energy Company Obligation? Energies 2018, 11, 2070. [CrossRef]

89. Geddes, A.; Schmidt, T.S.; Steffen, B. The multiple roles of state investment banks in low-carbon energy finance: An analysis of Australia, the UK and Germany. Energy Policy 2018, 115, 158-170. [CrossRef]

90. Haas, T.; Sander, H. Decarbonizing Transport in the European Union: Emission Performance Standards and the Perspectives for a European Green Deal. Sustainability 2020, 12, 8381. [CrossRef]

91. Goggins, G.; Fahy, F.; Jensen, C.L. Sustainable transitions in residential energy use: Characteristics and governance of urban-based initiatives across Europe. J. Clean. Prod. 2019, 237, 117776. [CrossRef]

92. Kasa, S.; Leiren, M.D.; Khan, J. Central government ambitions and local commitment: Climate mitigation initiatives in four municipalities in Norway and Sweden. J. Environ. Plan. Manag. 2012, 55, 211-228. [CrossRef]

93. Dobravec, V.; Matak, N.; Sakulin, C.; Krajačić, G. Multilevel governance energy planning and policy: A view on local energy initiatives. Energy Sustain. Soc. 2021, 11, 2. [CrossRef]

94. Wen, D.; Gao, W.; Kuroki, S.; Gu, Q.; Ren, J. The effects of the new Feed-In Tariff Act for solar photovoltaic (PV) energy in the wake of the Fukushima accident in Japan. Energy Policy 2021, 156, 112414. [CrossRef]

95. Bergman, N.; Foxon, T.J. Reframing policy for the energy efficiency challenge: Insights from housing retrofits in the United Kingdom. Energy Res. Soc. Sci. 2020, 63, 101386. [CrossRef]

96. Wood, G.; Dow, S. What lessons have been learned in reforming the Renewables Obligation? An analysis of internal and external failures in UK renewable energy policy. Energy Policy 2012, 39, 2228-2244. [CrossRef]

97. Hossain, E.; Roy, S.; Mohammad, N.; Nawar, N.; Dipta, D.R. Metrics and enhancement strategies for grid resilience and reliability during natural disasters. Appl. Energy 2021, 290, 116709. [CrossRef]

98. Frangou, M.; Aryblia, M.; Tournaki, S.; Tsoutsos, T. Renewable energy performance contracting in the tertiary sector Standardization to overcome barriers in Greece. Renew. Energy 2018, 125, 829-839. [CrossRef]

99. Hou, J.; Zhu, X.; Liu, P. Current situation and future projection of marine renewable energy in China. Int. J. Energy Res. 2019, 43, 662-680. [CrossRef]

100. Deng, J.; Liu, X.; Zhai, G. Robust Design Optimization of Electromagnetic Actuators for Renewable Energy Systems Considering the Manufacturing Cost. Energies 2019, 12, 4353. [CrossRef]

101. Perera, A.; Javanroodi, K.; Nik, V.M. Climate resilient interconnected infrastructure: Co-optimization of energy systems and urban morphology. Appl. Energy 2021, 285, 116430. [CrossRef]

102. Oleg, K. Marketing strategies and prognoses of development of the Renewable Energy market in Ukraine. Sci. Achivement Agric. Eng. 2017, 2, 100-121.

103. Rae, C.; Kerr, S.; Maroto-Valer, M. Upscaling smart local energy systems: A review of technical barriers. Renew. Sustain. Energy Rev. 2020, 131, 110020. [CrossRef]

104. Economidou, M.; Todeschi, V.; Bertoldi, P.; D’Agostino, D.; Zangheri, P.; Castellazzi, L. Review of 50 years of EU energy efficiency policies for buildings. Energy Build. 2020, 225, 110322. [CrossRef]

105. Lo, K. A critical review of China's rapidly developing renewable energy and energy efficiency policies. Renew. Sustain. Energy Rev. 2014, 29, 508-516. [CrossRef] 
106. Czarnitzki, D.; Hussinger, K. The Link between R\&D Subsidies, R\&D Spending and Technological Performance (August 2004). ZEW-Centre for European Economic Research Discussion Paper No. 04-056. Available online: https://ssrn.com/abstract=5753 62 (accessed on 30 November 2021).

107. Chen, C.; Yang, A. Power-to-methanol: The role of process flexibility in the integration of variable renewable energy into chemical production. Energy Convers. Manag. 2021, 228, 113673. [CrossRef]

108. Cheng, Y.; Yao, X. Carbon intensity reduction assessment of renewable energy technology innovation in China: A panel data model with cross-section dependence and slope heterogeneity. Renew. Sustain. Energy Rev. 2021, 135, 110157. [CrossRef]

109. Bilgen, S. Structure and environmental impact of global energy consumption. Renew. Sustain. Energy Rev. 2014, 38, 890-902. [CrossRef]

110. Razmjoo, A.; Shirmohammadi, R.; Davarpanah, A.; Pourfayaz, F.; Aslani, A. Stand-alone hybrid energy systems for remote area power generation. Energy Rep. 2019, 5, 231-241. [CrossRef]

111. Relva, S.G.; da Silva, V.O.; Gimenes, A.L.V.; Udaeta, M.E.M.; Ashworth, P.; Peyerl, D. Enhancing developing countries' transition to a low-carbon electricity sector. Energy 2021, 220, 119659. [CrossRef]

112. Vipul, D. The study on consumption of household appliances with SCADA platform. AIP Conf. Proc. 2021, $2335,040009$. [CrossRef]

113. Pierce, J. Home, habits, and energy: Examining domestic interactions and energy consumption. In Proceedings of the SIGCHI Conference on Human Factors in Computing Systems, Atlanta, GA, USA, 10-15 April 2010. [CrossRef]

114. Sally, B. Electricity Conservation in Context: A Mixed Methods Study of Residential Conservation Behaviour During an Electricity Shortage in New Zealand. 2009. Available online: http:/ / hdl.handle.net/10063/1099 (accessed on 30 November 2021).

115. Xu, Q.; Lu, Y.; Hwang, B.-G.; Kua, H.W. Reducing residential energy consumption through a marketized behavioral intervention: The approach of Household Energy Saving Option (HESO). Energy Build. 2021, 232, 110621. [CrossRef]

116. Koroleva, K.; Melenhorst, M.; Novak, J.; Gonzalez, S.L.H.; Fraternali, P.; Rizzoli, A.E. Designing an integrated socio-technical behaviour change system for energy saving. Energy Inform. 2019, 2, 30. [CrossRef]

117. Tsang, F.; Bruge, P.; Chatterton, T.; Wilson, C.; Diepeveen, S.; Drabble, S.; Guerin, B. What Works in Changing EnergyUsing Behaviours in the Home? A Rapid Evidence Assessment, 2012-UK Government. Available online: https: / / uwe-repository.worktribe.com/output/956059/what-works-in-changing-energy-using-behaviours-in-the-home-a-rapidevidence-assessment (accessed on 30 November 2021).

118. Fettermann, D.C.; Borriello, A.; Pellegrini, A.; Cavalcante, C.G.; Rose, J.M.; Burke, P.F. Getting smarter about household energy: The who and what of demand for smart meters. Build. Res. Inf. 2021, 49, 100-112. [CrossRef]

119. Sorrell, S.; Gatersleben, B.; Druckman, A. The limits of energy sufficiency: A review of the evidence for rebound effects and negative spillovers from behavioural change. Energy Res. Soc. Sci. 2020, 64, 101439. [CrossRef]

120. Capehart, B.L. Guide to Energy Management, International Version, 8th ed.; Routledge: London, UK, 2020. Available online: https: / / www.routledge.com/Guide-to-Energy-Management-Eighth-Edition---International-Version/Capehart-KennedyTurner/p/book/9781498779883 (accessed on 30 November 2021).

121. Guy, P. Advanced Introduction to Public Policy; Elgar Advanced Introductions Series. 2021. Available online: https://www.eelgar.com/shop/gbp/advanced-introduction-to-public-policy-9781781955772.html (accessed on 30 November 2021).

122. Jessoe, K.; Lade, G.E.; Loge, F.; Spang, E. Spillovers from Behavioral Interventions: Experimental Evidence from Water and Energy Use. J. Assoc. Environ. Resour. Econ. 2021, 8, 315-346. [CrossRef]

123. Muza, O.; Debnath, R. Disruptive innovation for inclusive renewable policy in sub-Saharan Africa: A social shaping of technology analysis of appliance uptake in Rwanda. Renew. Energy 2021, 168, 896-912. [CrossRef] [PubMed]

124. Mbaka, C.K. Spatial variation of household energy consumption across counties in Kenya. Afr. Geogr. Rev. 2021. [CrossRef]

125. Di Louie, G. Advanced Lighting Controls: Energy Savings, Productivity, Technology and Applications; Elsevier: Amsterdam, The Netherlands, 2021.

126. Gamma, K.; Mai, R.; Cometta, C.; Loock, M. Engaging customers in demand response programs: The role of reward and punishment in customer adoption in Switzerland. Energy Res. Soc. Sci. 2021, 74, 101927. [CrossRef]

127. Staddon, S.C.; Cycil, C.; Goulden, M.; Leygue, C.; Spence, A. Intervening to change behaviour and save energy in the workplace: A systematic review of available evidence. Energy Res. Soc. Sci. 2016, 17, 30-51. [CrossRef]

128. Qiao, W.; Yin, X. Understanding the impact on energy transition of consumer behavior and enterprise decisions through evolutionary game analysis. Sustain. Prod. Consum. 2021, 28, 231-240. [CrossRef]

129. Foxall, G.R. Behavioral Economics in Consumer Behavior Analysis. Behav. Anal. 2017, 40, 309-313. [CrossRef]

130. Foxall, G.R. Consumer Psychology in Behavioral Perspective; Beard Books; Original work published 1990; Frederick, MD, USA, 2004.

131. Foxall, G.R. Invitation to Consumer Behavior Analysis. J. Organ. Behav. Manag. 2010, 30, 92-109. [CrossRef]

132. Foxall, G.R. Interpreting Consumer Choice: The Behavioral Perspective Model; Routledge: New York, NY, USA, 2011.

133. Foxall, G.R. Consumer behavior analysis and the marketing firm: Bilateral contingency in the context of environmental concern. J. Organ. Behav. Manag. 2015, 35, 44-69. [CrossRef]

134. Foxall, G.R. Operant Behavioral Economics. Manag. Decis. Econ. 2016, 37, 215-223. [CrossRef]

135. Kahneman, D.; Tversky, A. Choices, values, and frames. Am. Psychol. 1984, 39, 341-350. [CrossRef]

136. Larsen, N.M.; Sigurdsson, V.; Breivik, J. The Use of Observational Technology to Study In-Store Behavior: Consumer Choice, Video Surveillance, and Retail Analytics. Behav. Anal. 2017, 40, 343-371. [CrossRef] 
137. Pollitt, M.G. The role of behavioural economics in energy and climate policy. In Handbook of the Fundamentals of Financial Decision Making; World Scientific: Singapore, 2013; pp. 269-278. Available online: https://www.econ.cam.ac.uk/research-files/repec/ cam/pdf/cwpe1165.pdf (accessed on 30 November 2021).

138. Camara, N.; Xu, D.; Binyet, E. Understanding household energy use, decision making and behaviour in Guinea-Conakry by applying behavioural economics. Renew. Sustain. Energy Rev. 2017, 79, 1380-1391. [CrossRef]

139. Hobman, E.V.; Frederiks, E.R.; Stenner, K.; Meikle, S. Uptake and usage of cost-reflective electricity pricing: Insights from psychology and behavioural economics. Renew. Sustain. Energy Rev. 2016, 57, 455-467. [CrossRef]

140. Mundaca, L.; Samahita, M.; Sonnenschein, J.; Seidl, R. Chapter 1.2-Behavioural economics for energy and climate change policies and the transition to a sustainable energy use-A Scandinavian perspective. Energy Behav. 2020, 45-87. [CrossRef]

141. Lefebvre, J.-F. Renewable Energy: Myths and Obstacles: Sustainable Energy Development and Hyropower Rehabilitation; Éditions Multimondes: Montréal, QC, Canda, 2013. Available online: https://franklin.library.upenn.edu/catalog/FRANKLIN_99779192 02603681 (accessed on 30 November 2021).

142. Hwang, B.-G.; Tan, J.S. Green building project management: Obstacles and solutions for sustainable development. Sustain. Dev. 2012, 20, 335-349. [CrossRef]

143. Gómez-Navarro, T.; Ribó-Pérez, D. Assessing the obstacles to the participation of renewable energy sources in the electricity market of Colombia. Renew. Sustain. Energy Rev. 2018, 90, 131-141. [CrossRef]

144. Khodadadzadeh, T. Green building project management: Obstacles and solutions for sustainable development. J. Proj. Manag. 2016, 1, 21-26. [CrossRef]

145. Solangi, Y.A.; Longsheng, C.; Shah, S.A.A. Assessing and overcoming the renewable energy barriers for sustainable development in Pakistan: An integrated AHP and fuzzy TOPSIS approach. Renew. Energy 2021, 173, 209-222. [CrossRef]

146. Aleixo, A.; Leal, S.; Azeiteiro, U. Conceptualization of sustainable higher education institutions, roles, barriers, and challenges for sustainability: An exploratory study in Portugal. J. Clean. Prod. 2018, 172, 1664-1673. [CrossRef]

147. Kazak, J.; van Hoof, J.; Szewrański, S. Challenges in the wind turbines location process in Central Europe-The use of spatial decision support systems. Renew. Sustain. Energy Rev. 2017, 76, 425-433. [CrossRef]

148. Ahmed, N.A.; Cameron, M. The challenges and possible solutions of horizontal axis wind turbines as a clean energy solution for the future. Renew. Sustain. Energy Rev. 2014, 38, 439-460. [CrossRef]

149. Bolinger, M.; Lantz, E.; Wiser, R.; Hoen, B.; Rand, J.; Hammond, R. Opportunities for and challenges to further reductions in the "specific power" rating of wind turbines installed in the United States. Wind. Eng. 2021, 45, 351-368. [CrossRef]

150. Grodsky, S.M.; Hernandez, R.R. Reduced ecosystem services of desert plants from ground-mounted solar energy development. Nat. Sustain. 2020, 3, 1036-1043. [CrossRef]

151. Voigt, C.C. Insect fatalities at wind turbines as biodiversity sinks. Conserv. Sci. Pract. 2021, 3, e366. [CrossRef]

152. Fthenakis, V.M. Thin-film Photovoltaic Cells: Health and Environmental Issues in their Manufacture Use and Disposal. Fthenakis, V.M.; Moskowitz, P.D. Thin-film Photovoltaic Cells: Health and Environmental Issues in their Manufacture Use and Disposal. Prog. Photovolt. Res. Appl. 1995, 3, 295-306. [CrossRef]

153. Golden, G.U. The Not-so-Green Renewable Energy: Preventing Waste Disposal of Solar Photovoltaic (PV) Panels. Gold. Gate Univ. Environ. Law J. 2010, 4, 329. Available online: https: / / digitalcommons.law.ggu.edu/cgi/viewcontent.cgi? referer $=\&$ httpsredir=1\& article $=1064 \&$ context=gguelj (accessed on 30 November 2021).

154. Helbig, C.; Bradshaw, A.M.; Kolotzek, C.; Thorenz, A.; Tuma, A. Supply risks associated with CdTe and CIGS thin-film photovoltaics. Appl. Energy 2016, 178, 422-433. [CrossRef]

155. Quaranta, E.; Wolter, C. Sustainability assessment of hydropower water wheels with downstream migrating fish and blade strike modelling. Sustain. Energy Technol. Assess. 2021, 43, 100943. [CrossRef]

156. Hossain, E.; Petrovic, S. Challenges of Renewable Sources of Energy. In Renewable Energy Crash Course; Springer: Cham, Switzerland, 2021. [CrossRef]

157. Sayed, E.T.; Wilberforce, T.; Elsaid, K.; Rabaia, M.K.H.; Abdelkareem, M.A.; Chae, K.-J.; Olabi, A. A critical review on environmental impacts of renewable energy systems and mitigation strategies: Wind, hydro, biomass and geothermal. Sci. Total Environ. 2021, 766, 144505. [CrossRef] [PubMed]

158. Kuriqi, A.; Pinheiro, A.N.; Sordo-Ward, A.; Bejarano, M.D.; Garrote, L. Ecological impacts of run-of-river hydropower plantsCurrent status and future prospects on the brink of energy transition. Renew. Sustain. Energy Rev. 2021, 142, 110833. [CrossRef]

159. Vidadili, N.; Suleymanov, E.; Bulut, C.; Mahmudlu, C. Transition to renewable energy and sustainable energy development in Azerbaijan. Renew. Sustain. Energy Rev. 2017, 80, 1153-1161. [CrossRef]

160. Afsharzade, N.; Papzan, A.; Ashjaee, M.; Delangizan, S.; Van Passel, S.; Azadi, H. Renewable energy development in rural areas of Iran. Renew. Sustain. Energy Rev. 2016, 65, 743-755. [CrossRef]

161. Yatim, P.; Mamat, M.-N.; Mohamad-Zailani, S.H.; Ramlee, S. Energy policy shifts towards sustainable energy future for Malaysia. Clean Technol. Environ. Policy 2016, 18, 1685-1695. [CrossRef]

162. Ribeiro, J.M.P.; Autran, A.; Santa, S.B.; Jonck, A.V.; Magtoto, M.; Faraco, R.Á.; Guerra, J.B.A. Identifying and Overcoming Communication Obstacles to the Implementation of Green Actions at Universities: A Case Study of Sustainable Energy Initiatives in South Brazil. In Universities as Living Labs for Sustainable Development; World Sustainability Series; Springer: Cham, Switzerland, 2020. [CrossRef] 
163. Cristino, T.M.; Lotufo, F.; Delinchant, B.; Wurtz, F.; Neto, A.F. A comprehensive review of obstacles and drivers to building energy-saving technologies and their association with research themes, types of buildings, and geographic regions. Renew. Sustain. Energy Rev. 2021, 135, 110191. [CrossRef]

164. Anuar, M.R.; Abdullah, A.Z. Challenges in biodiesel industry with regards to feedstock, environmental, social and sustainability issues: A critical review. Renew. Sustain. Energy Rev. 2016, 58, 208-223. [CrossRef]

165. Cataldo-Born, M. Obstacles and motivations for earthbag social housing in Chile: Energy, environment, economic and codes implications. Rev. Construcción 2016, 15, 17-26. [CrossRef]

166. Wang, Y.; Fang, X.; Yin, S.; Chen, W. Low-carbon development quality of cities in China: Evaluation and obstacle analysis. Sustain Cities Soc. 2021, 64, 102553. [CrossRef]

167. Kopteva, A.; Kalimullin, L.; Tcvetkov, P.; Soares, A. Prospects and Obstacles for Green Hydrogen Production in Russia. Energies 2021, 14, 718. [CrossRef]

168. Sen, S. Opportunities, barriers and issues with renewable energy development-A Discussion. Renew. End Sustain. Energy Rev. 2017, 69, 1170-1181. [CrossRef]

169. Mandelli, S.; Barbieri, J.; Mattarolo, L.; Colombo, E. Sustainable energy in Africa: A comprehensive data and policies review. Renew. Sustain. Energy Rev. 2014, 37, 656-686. [CrossRef]

170. Shyu, C.-W. A framework for 'right to energy' to meet UN SDG7: Policy implications to meet basic human energy needs, eradicate energy poverty, enhance energy justice, and uphold energy democracy. Energy Res. Soc. Sci. 2021, 79, 102199. [CrossRef] 